\title{
The Economic And Social Effects Of Farmers Growing Para Rubber In Northeast Thailand: A Case Study Of Sapsomboon Village, Dun Sad Sub-District, Kranoun District, Khon Kaen Province
}

\author{
Patarapong Kroeksakul, Prince of Songkla University, Thailand \\ Aree Naipinit, Khon Kaen University, Thailand \\ Thongphon Promsaka Na Sakolnakorn, Prince of Songkla University, Thailand
}

\begin{abstract}
This article presents the economic and social effects of farmers growing para rubber in Northeast Thailand. We did in-depth interviews with government officials and farmers involved in the para rubber project implemented by Thailand's government. From the study, we found that farmers growing para rubber have more income and a better quality of life. In addition, the social status of farmers growing para rubber is elevated within the community because their wealth is greatly increased after they sell their liquid para rubber.
\end{abstract}

Keywords: para rubber; farmer; social change; Northeast Thailand

\section{INTRODUCTION}

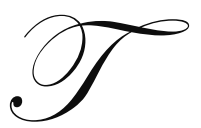

he Isan region of Northeast Thailand is $170,218 \mathrm{~km}^{2}$ and agriculture is its main economic activity. However, due to its socioeconomic conditions and hot, dry climate, its output lags behind that of other parts of the country. Isan is Thailand's poorest region (Mongkolsawat, 2006). In addition, rainfall in the northeast averages between 1200 and 1300 millimeters per year (Royal Irrigation Department, 2006) and farmers there grow agricultural products that they can produce in the rainy season (Aunno, 2003). Agriculture production in the northeast changed in 1961 when the government set up a policy to expand agriculture in that region. Afterward, farmers in the northeast started to grow cassava, sugarcane, and para rubber (during the first through fourth national economic and social development plans of Thailand; Thongpan, 1993).

Farmers have grown para rubber in the southern part of Thailand since 1899. However, in 1990, the Office of Support Fund for Growing Para Rubber supported a project promoting the growing of para rubber in northeast Thailand to increase revenue for farmers. The first project involved plantations in three provinces of northeast Thailand; namely, Nongkai, Surin, and Burirum. In 1999, the proportion of Thailand's land area used for rubber plantations was 5,047,516 acres. Para rubber planting areas have been increasing by $1.34 \%$ each year (OAE, 2004). As mentioned above, production of para rubber is increasing because the Thai government has launched many projects geared toward increasing the number of rubber plantations. The goal is to solve the problem of poverty, especially for people in the rural northeast, and to increase the foliage in areas with low soil fertility by planting para rubber trees. However, para rubber planting is a new agricultural venture in northeast Thailand. In 2009, about 240,000 hectares (ha), 9.5\% of the agricultural area in the northeast, were used for rubber plantations. In addition, when Sarawadee et al. (2007) were attempting to develop a strategy for managing para rubber plantations in the northeast, they found that marketing is one issue affecting management. This is because the northeast region is far from para rubber traders (most are in southern Thailand). Moreover, Laura (2006) discovered that para rubber 
plantations in the northeast faced the problems of diminished soil fertility, high temperatures, and low humidity unsuitable for planting para rubber. Montri et al. (2010) explained that workers on para rubber plantations in the northeast lack skills and knowledge of how to manage their farms.

In 2007, researchers conducted in-depth interviews with farmers who plant para rubber in Khon Kaen and Chaiyaphum provinces, which revealed problems with marketing, labor, skill, and knowledge. As mentioned above, para rubber plantations in the northeast face many business management problems. Therefore, this paper will study the economic and social effects of para rubber plantations in the northeast and will be of benefit to farmers or business entrepreneurs who want to set up para rubber plantations in the near future.

\section{OBJECTIVE}

To study the economic and social changes caused by growing para rubber in northeast Thailand.

\section{METHODOLOGY}

This study was conducted in 2009 using qualitative methods and in-depth interviews of (1) government officials at the Office of the Rubber Replanting Aid Fund (OORAF) at Khon Kaen and (2) farmers who plant para rubber. In addition, this study surveyed different types of farmers as well as their activities and social structures, such as households, groups, and communities.

The area of this study is the Kranoun district, Khon Kaen province, because Kranoun is the most important district in the Khon Kaen province for rubber plantations. The village of Sapsomboon was selected for in-depth interviews of farmers because more than $50 \%$ of the population in this village plants para rubber. The study site is shown in Figure 1.

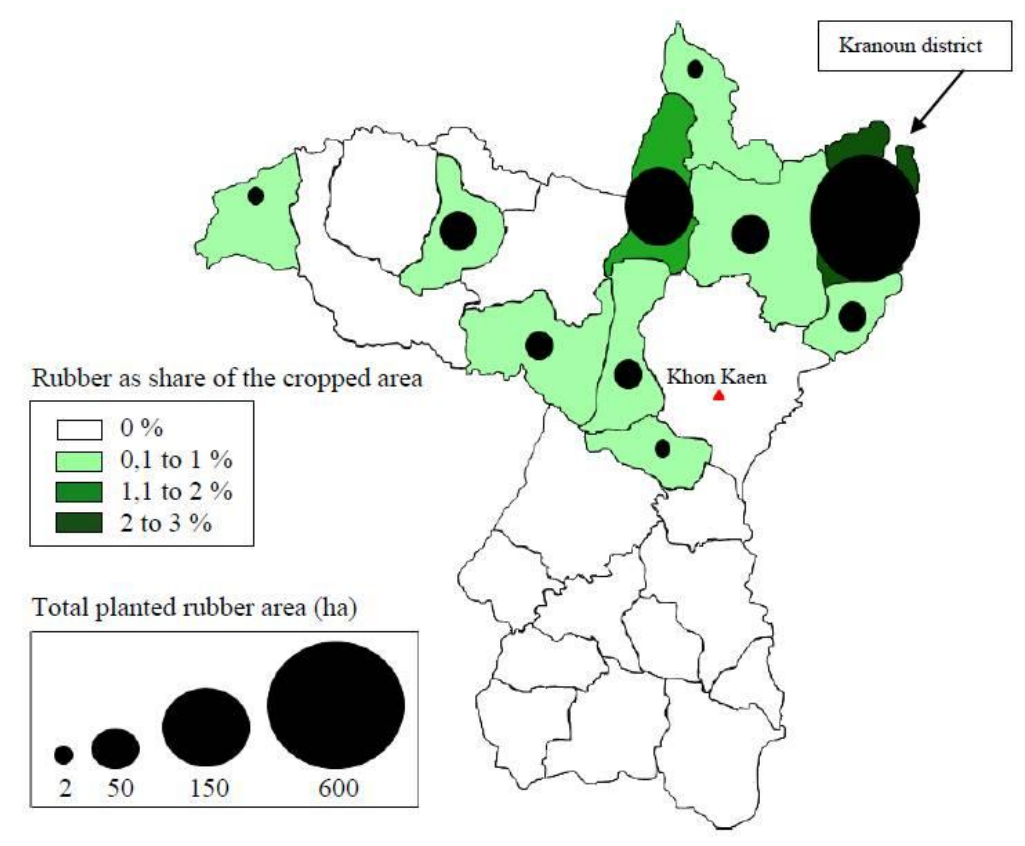

Figure 1: Density of Para Rubber Plantations in Khon Kaen Province 


\section{CHARACTERISTICS OF THE STUDY AREA}

Sapsomboon is far from the Maung district (Khon Kaen province) - about $85 \mathrm{~km}$. The land is $240-260 \mathrm{~m}$ above sea level and the soil is sandy. Rainfall averages $1300 \mathrm{~mm}$ per year. The geography of Sapsomboon is shown in Figure 2.

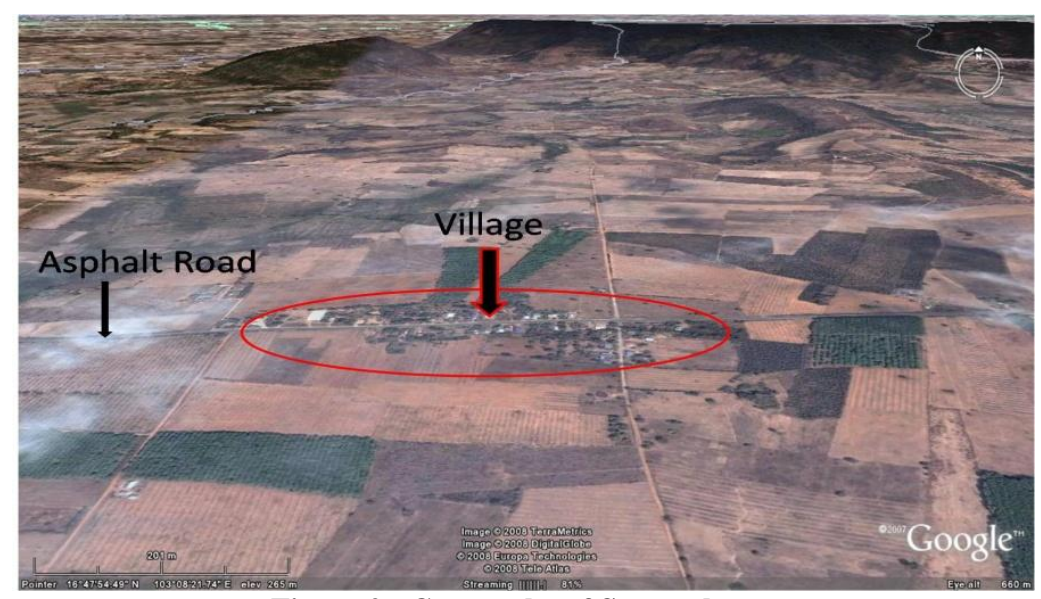

Figure 2: Geography of Sapsomboon

Source: Google earth

As to the village's land use, out of a total area of 215 ha, about 10 ha are classified as settled land (5\%) and 204 ha are classified as agricultural land. Agricultural areas are used for growing several different crops, including para rubber $(60 \%)$, sugarcane $(17 \%)$, paddy fields (15\%), cassava $(4 \%)$, eucalyptus $(2 \%)$, and other crops, like Kissana, chili, and peanuts (2\%). The village has 96 ha for planting para rubber, averaging 2.6 ha per household. The plantations can be divided into three groups based on size. Large farmers own more than 3.5 ha (22\% of all farmers in the village), medium farmers own between 1.7 and 3.4 ha (43\% of all farmers in the village), and small farmers own less than 1.6 ha ( $35 \%$ of all farmers in the village).

The village has 76 households with 319 villagers; 76 are $0-15$ years old, 206 are 16-60 years old, and 37 are over 60 years old. All of the people in this village are Buddhist and they use the Isan language for communication. Isan is the collective name for the dialects of the Lao language as they are spoken in Thailand. It is spoken by approximately 20 million people who live and/or come from the northeast region of Thailand. The study revealed that 44 households, or $58 \%$ of all villagers, grow para rubber.

Prior to 1950, farmers in Sapsomboon grew kenaf and cotton. In 1950, they began growing paddy; in 1964, cassava; in 1984, sugarcane; and in 1992, para rubber. Also in 1992, the Office of the Rubber Replanting Aid Fund (OORAF) began providing funds to farmers who wanted to plant para rubber, such as for digging holes, plowing, land management, and fertilizer. Eleven households in Sapsomboon became members of OORAF and received funds for growing para rubber. The number increased to 37 in 1997 and 44 households in 2009.

\section{SURVEY RESULTS}

\section{Income}

In 2008, the total combined incomes of all households in Sapsomboon was $11,157,800$ baht per year (approximately US \$371,927), averaging 146,813 baht per household per year. Villages derive income from various agricultural products, including para rubber, cassava, sugarcane, and rice. The total income from para rubber is $3,790,000$ baht (approximately US \$126,333). 


\section{Expenditures}

The village's total expenses were 8,525,650 baht in 2008 (approximately US \$284,188), averaging 112,179 baht per household per year (approximately US $\$ 3,739$ ). In addition, their expenses are divided into two parts: 1) agricultural investment totals 4,037,230 baht per year (approximately US $\$ 134,574,47 \%$ of total expenditures) and 2) general expenditures, such as food, gasoline, clothing, and everyday essentials, total $4,488,420$ baht per year (approximately US $\$ 149,164,53 \%$ of total expenditures).

\section{Labor}

The labor for para rubber plantations is mostly provided by the owner's family. Such plantations generally employ only two to three workers who live in surrounding areas.

\section{Marketing}

In the production of para rubber, villagers sell liquid rubber to traders, who then send it to factories in the Udonthani, Khon Kaen, Kalasin, Roi-Et, and Chaiyaphum provinces.

\section{Market Price}

World market prices for rubber products are determined by supply and demand. The quotations are readily available from international markets. A committee established by the Ministry of Agriculture and Cooperatives and the Thai Rubber Association announces official rubber (Hat Yai and FOB Bangkok) prices daily. It disseminates these prices throughout the country by radio and in newspapers. The rubber prices for various markets are disseminated on the radio, in newspapers, and on the Internet. The large and well-equipped para rubber growers can usually access these market prices through Thailand's well-developed telephone system. The word-of-mouth system of information dissemination among small para rubber growers functions well in the rural areas. The rubber growers were thus well informed and up-to-date about market prices.

\section{Social Status}

The price of rubber production affects the farmers' status as it can increase their income. People call an owner of a para rubber plantation a "rich man." Owners' social status is high because they have more money compared with farmers growing other agricultural products. Owning a para rubber plantation can also improve their quality of life, so they can spend money on family necessities, such as a car, motorcycle, or TV, and build and/or repair their house. Therefore, many farmers in suitable areas in the northeast (such as in mountainous areas) are changing their agriculture production to para rubber because they want more money to improve their quality of life.

\section{CONCLUSION}

Areas with rubber plantations have been increasing in the northeast region of Thailand because the government has been promoting them and the price of liquid para rubber is very good. However, para rubber has also positively affected the livelihoods of farmers, raising their income more than another agricultural product would, and the growth of para rubber is expanding to forested areas (Marjam, 2008). Miguel et al. (2010) explained that para rubber is of high value to farmers because of its high world demand - many products can be made from rubber. In addition, farmers growing para rubber learn how to mix fertilizer themselves as well as how to produce bio-fertilizer and organic fertilizer to lower production costs. Besides reducing costs, their production of such fertilizer preserves soil fertility. Therefore, farmers who grow para rubber throughout northeast Thailand require education on fertilizers. However, growers of para rubber in the northeast suffer from limited land for planting as successful plantations depend on location and atmosphere, and most of the area in the northeast is dry (para rubber trees require humid weather). 


\section{AUTHOR INFORMATION}

Dr. Patarapong Kroeksakul is a lecturer at the Faculty of Natural Resources, Prince of Songkla University, Thailand. He received his Ph.D. in agriculture systems from Khon Kaen University, Thailand. He is a specialist in socioeconomic and agriculture systems. His contact e-mail is patarapong.k@psu.ac.th

Dr. Aree Naipinit is an assistant professor at the Department of Management of the Faculty of Management Science, Khon Kaen University, Thailand. She received her Ph.D. in public administration from Magadh University, India. She specializes in SME management and strategic management. Her contact e-mail is: chokanan_kk@hotmail.com

Dr. Thongphon Promsaka Na Sakolnakorn is a lecturer of the Faculty of Liberal Arts at the Prince of Songkla University, Thailand. He received his first Ph.D. in development science from Khon Kaen University, Thailand, and his second doctoral degree in Ancient Indian and Asian studies from Magadh University, India. He specializes in outsourcing management, organization development, and SME management. His contact e-mail is: thongphon.p@psu.ac.th.

\section{REFERENCES}

1. Aunno, A. 2003. Sustainable Agriculture of Thai Social. Thailand, Nonthaburi: Sustainable agriculture foundation.

2. Laura, R. 2006. Rubber plantation performance in Northeast and East of Thailand in relation to environmental conditions. Thesis Master Degree in Forestry Ecology. University of Helsinki. Finland.

3. Miguel, M., Pinto, F., Gulyurtlu, I., Cabrita, I., Nogueira, C. A. and Matos, A. 2010. Response surface methodology optimization applied to rubber tyre and plastic wastes thermal conversion. Fuel, 89(9), 2217 2229.

4. Mirjam, A. F. R., Andel, T. V., Morsello, C., Otsuki, K., Rosendo, S. and Scholz, I. 2008. Forest - related partnerships in Brazilian Amazonia: There is more to sustainable forest management than reduced impact logging. Forest Ecology and Management, 256(7), 1482 - 1497.

5. Mongkolsawat, C. 2006. Efficiency of Isaan Region for development. Khon Kaen University: IT center for Northeast region development.

6. Montri, S., Aengwanich, W. and Ieamvijarn, S. 2010. A Model of appropriate self - adjustment of farmers who grow para rubber (Hevea brasiliensis) in Northeast Thailand. Journal of Social Sciences 6(2), 167 169.

7. Office of Agricultural Economics (OAE). 2004. Thailand Agricultural Statistic. Thailand: Center of agriculture statistic, office of agriculture economics of Ministry of Agriculture and Cooperatives.

8. Royal Irrigation Department. 2006. Chi basin. Retrieved on 9 December 2009 from, http://www.rid.go.th/b4-chi.htm.

9. Sarawadee, D., Pawat, P. and Choungcham, S. 2007. Community economic of Isaan region, Case study para rubber group (Research Report). Khon Kaen University Research and Development Institute.

10. Thongpan, S. 1993. Thailand Policy of Agriculture (Reprint $2^{\text {st }}$ ). Bangkok: Lerdchai printing. 


\section{NOTES}

